\title{
NURSE-LED INTERVENTION ON TEACHERS' KNOWLEDGE AND MANAGEMENT OF PUPILS WITH ATTENTION DEFICIT HYPERACTIVITY DISORDER IN PRIMARY SCHOOLS IN ABEOKUTA, OGUN STATE
}

\author{
Alake Oluwaseun Morolake', Professor Joseph Aina², \\ Sodimu Jeminat Omotade ${ }^{3}$ and Dele-Alonge Olajumoke ${ }^{4}$ \\ ${ }^{1}$ Department Of Psychiatry and Mental Health, School of Nursing, Babcock University, \\ Ilishan Remo, Ogun State, Nigeria. E-mail: aayoifemi@gmail.com \\ ${ }^{2}$ Department of Psychiatry and Mental Health, School of Nursing, Babcock University, \\ Ilishan Remo, Ogun State, Nigeria. Email: ainajoe @ gmail.com \\ ${ }^{3}$ School of Nursing, Abeokuta, Ogun State, Nigeria. Email: tadesodimu@gmail.com \\ ${ }^{4}$ School of Nursing, Abeokuta, Ogun State, Nigeria. Email: jakinlua@ yahoo.com
}

\begin{abstract}
Cite this article:
Alake O.M., Aina J., Sodimu J.O., Dele-Alonge O. (2022), Nurse-Led Intervention on Teachers' Knowledge and Management of Pupils with Attention Deficit Hyperactivity Disorder in Primary Schools in Abeokuta, Ogun State. African Journal of Health, Nursing and Midwifery 5(1), 1-14. DOI: 10.52589/AJHNMTGBIXVFY
\end{abstract}

\section{Manuscript History}

Received: 11 Dec 2021

Accepted: 29 Nov 2021

Published: 6 Jan 2022

Copyright $(9) 2020$ The Author(s). This is an Open Access article distributed under the terms of Creative Commons AttributionNonCommercial-NoDerivatives 4.0 International (CC BY-NC-ND 4.0 ), which permits anyone to share, use, reproduce and redistribute in any medium, provided the original author and source are credited.
ABSTRACT: The objective of any educational system is to provide education for all learners with diverse needs and abilities to enable them to achieve their potential and subsequently contribute to society. Teachers are in a position to be the first to suspect that a child might have Attention Deficit Hyperactivity Disorder (ADHD) because they are with them for most of the day and they know how normal learners typically behave in classroom situations. One group pre-test post-test quasi-experimental study was employed for this study. The population comprised 42 teachers in the selected schools. Total enumeration was used for the study. A self-structured questionnaire was validated and used to collect data. The Cronbach Alpha reliability coefficient of the construct ranged from 0.741 to 0.808 . Data collected were analyzed using descriptive and inferential statistics. The results showed $45.2 \%$ participants had low knowledge, $18.1 \%$ and $16.7 \%$ had moderate and high knowledge respectively at the pre-intervention stage while at the post-intervention stage, $14.3 \%$ had low knowledge score while $21.4 \%$ and $64.3 \%$ had moderate and high knowledge scores respectively. Also, at the pre-intervention stage of this study, it was found that $64.3 \%$ participants had a bad management score of ADHD while $35.7 \%$ had a good management score of ADHD. The result indicated that there is a non-significant difference in the post intervention knowledge and management of ADHD among the respondents as a p-value of 0.494 was recorded which is much greater than the alpha $(\alpha)$-value of 0.05 . The study concluded that the role of teachers in the identification and management of ADHD cannot be overlooked. This shows that training and proper education of the teachers will go a long way in the management of attention deficit in the pupils. The study recommended that the management of ADHD should be included in educational programs. Also, there should be follow-up to monitor the progress of the teachers in the management of children with ADHD.

KEYWORDS: Attention Deficit Hyperactivity Disorder, Intervention, Knowledge, Management, Primary School Teachers. 


\section{INTRODUCTION}

\section{Background to the Study}

Education is an important aspect of a child's development. Teachers are pertinent in the development of early childhood and their understanding and knowledge of serious problems that can hinder this development is very important to the educational development of these children. A childhood condition that can affect the early education of children is a condition known as attention deficit hyperactivity disorder (ADHD). This is a chronic condition which may extend through childhood into adulthood.

The objective of any educational system is to provide education for all learners with diverse needs and abilities to enable them to achieve their potential and subsequently contribute to society. Teachers can play a key role in identifying and supporting students with attention deficit hyperactivity disorder (ADHD). In order to fulfil this role, it is vital for these teachers to have adequate knowledge about this disorder. Teachers are in a position to be the first ones to suspect that a child might have ADHD because they are with them for most of the day and they know how normal learners typically behave in classroom situations. Teachers are usually the main source of knowledge and therefore could play an essential role in the diagnosis, management and treatment of those children with this condition.

Attention deficit hyperactivity disorder (ADHD) is one of the common childhood neurodevelopmental disorders which is often associated with disturbed classroom behavior (McCarthy, Wilton, Murray, Hodgkins \& Wong, 2012) and one of the most frequent reasons for referral to school psychologists (Polanczyk \& Rohde, 2017). The inattention, impulsivity and hyperactivity which are the major symptoms of ADHD are usually evident in the classroom, placing the teachers in a unique position to identify and refer such students for further assessment (Raman \& Van, 2013). However, studies have shown that some of these teachers have limited knowledge about ADHD and often provide inappropriate information about the condition to parents (Kos, Richdale \& Jackson, 2014).

Currently, there is a debate about ADHD diagnosis because the percentage of learners diagnosed is increasing past the generally accepted mark of $3 \%$ of the general population. ADHD affects a wide range of children with prevalent figures varying from $1 \%$ to $20 \%$, with boys showing more symptoms than girls. Studies on ADHD in Nigeria show a prevalence of $8.7 \%$ in the south west (Oke, Oseni, Adejuyigbe \& Mosaku, 2019). There is a high rate of parental referrals by teachers to doctors for children who display symptoms of attention deficit hyperactivity disorder, that is inattentiveness, impulse control, concentration problems and learning disabilities (Perold et al., 2018). More often than not, a learning disability is mistaken for ADHD because it often coexists with other clinical conditions. Learning disabilities (LD) and ADHD are distinctive neurologically-based disorders that are diagnosed and treated differently (Perold et al., 2018). The teacher is most often the first person to make a referral for assessment for ADHD (Malen, 2018). This happens because the structured school environment means children with problems of inattention, hyperactivity and impulsivity exhibit behaviours with which the other children and their teachers cannot cope (Malen, 2018).

In order to effectively operationalize inclusive education, teachers need to be conversant about the diversity of students in their classrooms,including those with ADHD. Recognizing the symptoms and having adequate knowledge about ADHD is important. For instance, if a teacher 
is highly knowledgeable about ADHD, it might increase the likelihood that such a teacher may refer a student showing characteristics of ADHD for assessment. Despite the importance of teachers' knowledge of ADHD, little research has been conducted and mixed results have been reported regarding the level of teachers' knowledge of ADHD (Ohan, Cormier, Hepp, Visser \& Strain, 2018).

Sherman, Rasmussen, and Baydala (2018) opined that teachers should play important roles in identifying children who need additional support by making referrals for their assessment, and being able to manage them in the classroom. Several studies from different parts of the world have found that teachers' knowledge is at best reasonable but in many cases, insufficient and requiring intervention (Nur \& Kavakc, 2018; Perold, Louw \& Kleynhans, 2018). As a result of the challenges that a child with ADHD poses in the classroom, reports show that teachers' attitudes toward children with ADHD may be negative due to insufficient knowledge. It is important for teachers to have a working knowledge of ADHD in order to adapt the curriculum, teaching methodologies and classroom management strategies to facilitate the academic, social and behavioral success of such children. Teachers need to organize their environments according to the diverse needs of the learners in the classroom. Having a better understanding may prevent them from developing negative views of these learners or labeling them (Holz \& Lessing, 2019).

According to McCarthy et al. (2014), ADHD has high prevalence with at least one pupil per classroom, and this could be a challenge for all the professionals that come in contact with them, especially teachers. Children with ADHD experience significant difficulties with behavior, social functioning, and academic performance in the classrooms. ADHD can affect children's academic achievement, well-being and social interactions.

Teachers' knowledge and understanding of this condition will determine how they engage with and manage learners experiencing ADHD. Early identification and intervention by teachers is very important especially as a large percentage of these pupils continue to experience symptoms in adolescence and adulthood (Adeosun, Ogun, Fatiregun \& Adeyemo, 2019). Teachers should be knowledgeable about this disorder and also have an understanding of the vital skills required in working with school children with ADHD in the regular classroom settings (Sarraf, Karahmadi, Marasy \& Azhar, 2014). There is a need for teachers to have an understanding of ADHD which could help them any time they encounter these pupils in their classrooms; they can help them not only academically but in a holistic manner. This in turn may help boost the children's self-esteem and strengthen their resilience; it may in turn bring a positive attitude to the pupil (Moldavsky \& Sayal, 2013). It is in view of this that the researcher became interested in this study.

\section{Theoretical Framework}

Kolb's experiential learning theory is one of the best-known educational theories in higher education. The theory presents a way of structuring a session or a whole course using a learning cycle. The different stages of the cycle are associated with distinct learning styles. Individuals differ in their preferred learning styles.

Experiential Learning Theory (ELT) represents a holistic educational structure called for by a number of educational stakeholders (Eyler, 2009). ELT is a synthesis of work from key theorists (Dewey, 1934, 1938, 1958; Freire, 1974; James, 1890; Jung, 1960, 1977; Lewin, 
1951; Rogers, 1961) built upon the foundational definition of learning as the "process whereby knowledge is created through the transformation of experience" (Kolb, 1984, p. 38). This transformation of experience occurs in a cyclical fashion as learners engage in concrete experiences (CE), reflective observation (RO), abstract conceptualization (AC), and active experimentation (AE) (Kolb, 1984). In this learning process, discourse is resolved through the transformation of new information and the grasping or accommodation into existing schema (Kolb, 1984). Experiential instruction is characterized by: (a) a continuous learning process grounded in experience, (b) a process requiring the resolution of conflicts between dialectically opposed modes of adapting to the world, (c) a holistic process of adapting to the world, (d) learning involving transactions between the person and the environment, and (e) a process of creating knowledge (Kolb, 1984). Learning, when viewed experientially, is more focused on the process than the products, highlighting the development of meta-cognitive skills critical to lifelong learning (Baker et al., 2012). This approach to learning has been shown to increase student satisfaction in the course, improve retention of information as measured on examinations, develop a deeper and more complex understanding of concepts, improve practical use of information, and develop meta-cognitive skills useful in all domains (Steinke \& Buresh, 2002).

Experiential learning theory integrates existing experiential, perceptive, cognitive, and behavioural theories of learning and development.

According to Kolb (1984), experiential learning is characterized by six core tenets:

1. Learning is a process.

2. Learning is grounded in experience.

3. Learning involves mastery of all four learning modes.

4. Learning is a holistic process of adaptation.

5. Learning occurs when an individual interacts with his/her environment.

6. Knowledge is created through learning. 


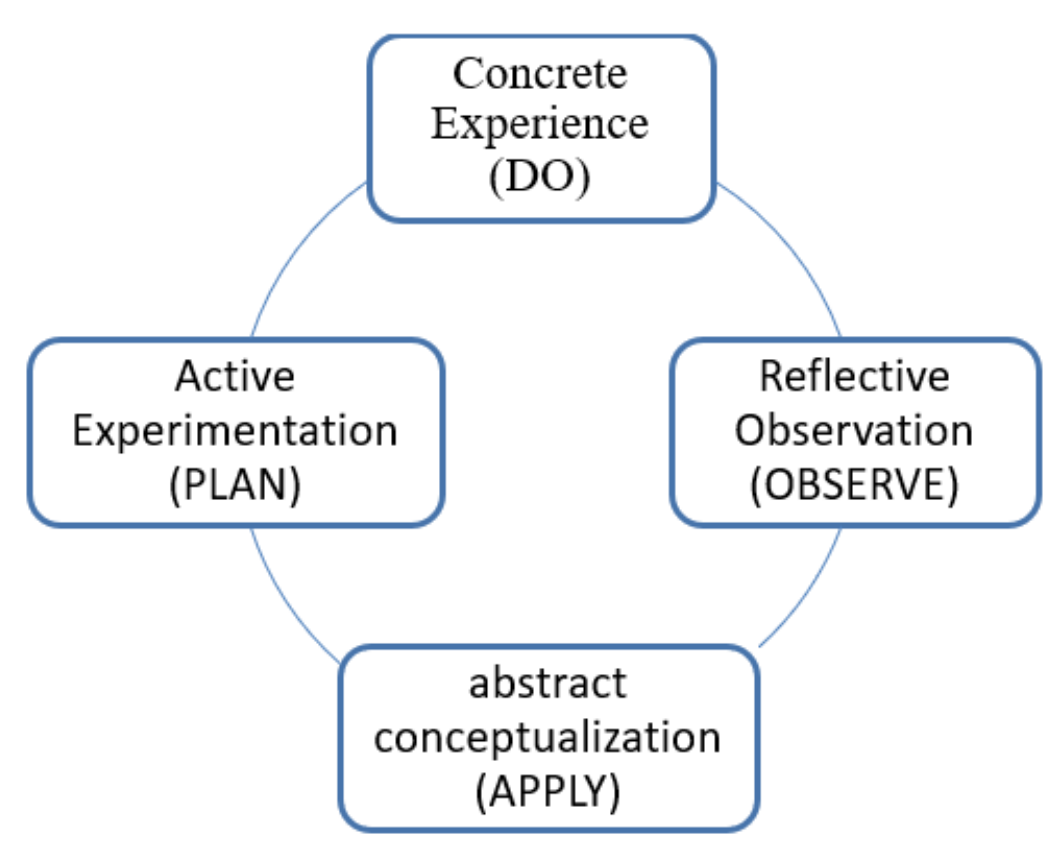

Figure 2.1: Kolb's Experiential Learning (Kolb,2014).

Learning Involves Mastery of all Four Learning Modes: Learning is a tension-filled process achieved through four learning modes: Concrete Experience (CE), Reflective Observation (RO), Abstract Conceptualization (AC) and Active Experimentation (AE). This is referred to as Kolb's learning cycle. In order for learning to be effective, the learner needs to master all four learning modes. Mastery of all four learning components, however, is complicated by Kolb's suggestion that "learning requires abilities that are polar opposites" (Evans et al., 2010).

$\mathrm{CE}$ and $\mathrm{AC}$ compose an apprehending/grasping dimension, while $\mathrm{AE}$ and $\mathrm{RO}$ form a transforming/processing dimension. Each dimension includes two opposite ways of adapting to the world. These are the conflict between experience and conceptualization (grasping dimension) and the conflict between reflection and action (processing dimension). Ultimately, the way the conflict gets resolved between these opposed learning modes determines the level of learning that occurs, with most effective learning resulting from a balance and integration of all four modes (Evans, 2010).

\section{Application of the Theory to the Study}

This was done to ensure that the educator is challenged to address the knowledge of identification of signs of ADHD using each of the learning dimensions, thereby encouraging integration of all four learning modes. The teachers are encouraged to reflect on their previous learning experiences if there are any and general experiences in the classroom (concrete experience), and to review some form of reference materials. They are then asked to transfer their new thoughts to a practice scenario before practicing their skills or going back to their own classroom to apply what they have learnt. More specifically, the teachers will be asked to complete a questionnaire pre-intervention which allows researchers to identify their level of 
knowledge, experiences and management skills. The interventions are analyzed and are shared within the class to allow for continual self-reflection; the learners may return to lecture materials several times throughout the training to add new reflections based on the comments of others and any information learned (reflective observation). Instead of using only a formal lecture to present the lecture notes to the learner, the study guide will allow the learner to follow a pattern of training using the information provided in the World Health Organization's Mental Health Gap Action Programme Intervention Guide (MhGAP-IG).

Applying the reference material to practice, the teachers apply what they have read by working through a series of group events they might have come across in their line of profession. Also, in order to practice the skills necessary for intervention in cases of suspected ADHD, teachers role-play potential real-world situations using a number of signs of ADHD learnt to help alleviate any boredom they might experience during this training (abstract conceptualization). The training then ends with teachers problem-solving and creating a list of strategies they can use to enhance the welfare of their students with signs of ADHD, along with a plan on when and how to implement these strategies in their own classroom settings (Active experimentation).

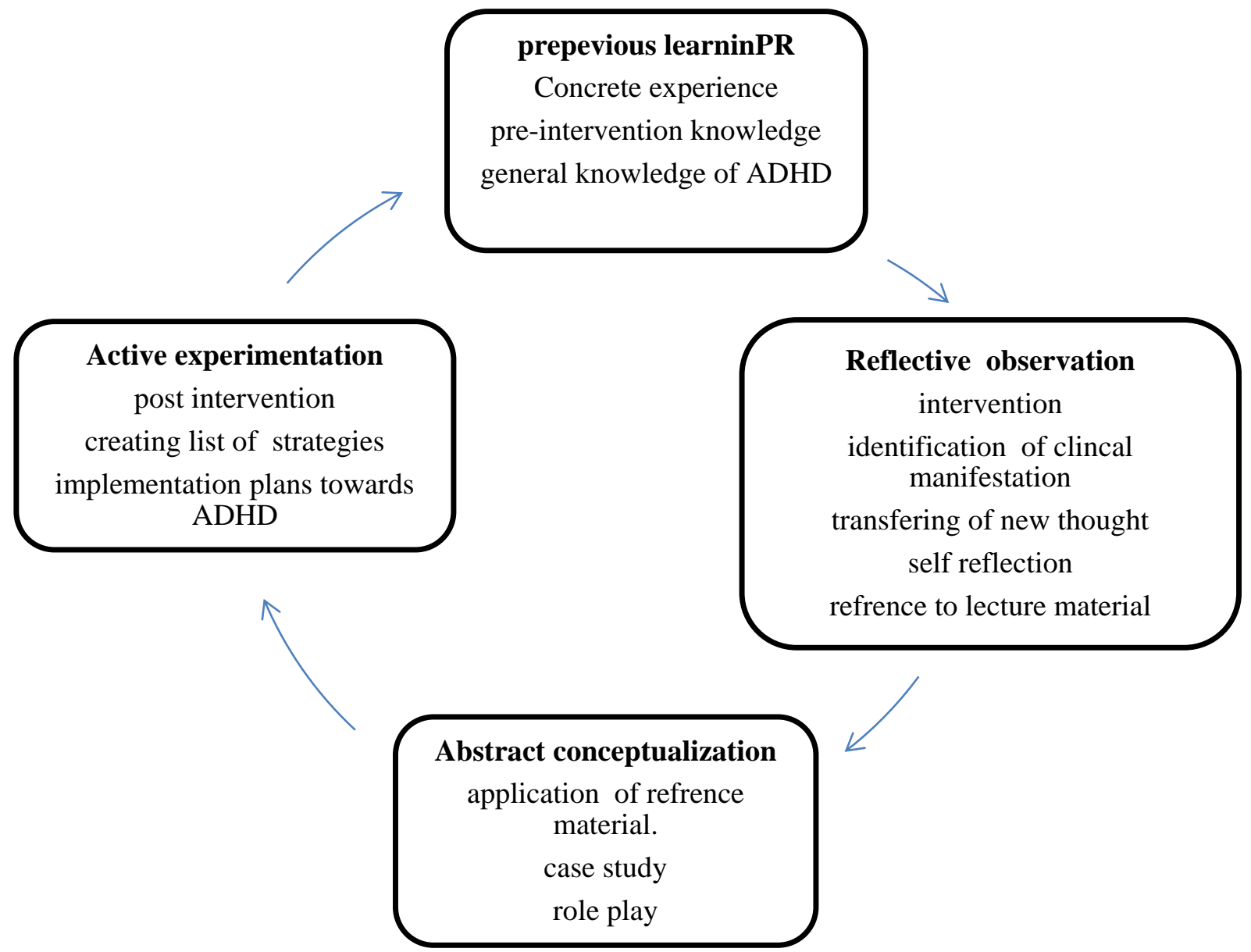

Figure 2.2: Adaptation of Kolb's Experiential Learning Theory (Kolb, 2014). 


\section{METHODOLOGY}

\section{Research Design}

This quantitative research design employed one group pre-test post-test quasi-experimental study to assess teachers' knowledge and classroom management of attention deficit hyperactivity disorder among pupils in selected primary schools in Abeokuta South Local Government Area.

\section{Population}

These are primary school teachers in Abeokuta South Local Government Area in Ogun State.

\section{Target Population}

The target population for the study include teachers from the two selected public primary schools in Abeokuta, Ogun State, Nigeria. Teachers from all classes in the selected schools will participate in the study and complete the adopted Knowledge of Attention Deficit Disorders Scale (KADDS) .

Inclusion Criteria: Any teacher working in the selected schools and is willing to participate in the study.

Exclusion Criteria: Any teacher on leave or special assignment away from the school during the study will be excluded from the study.

\section{Sample Size Determination}

The samples for this study were teachers of selected government primary schools in Abeokuta, Ogun State. A total enumeration sample was used for this study.

\section{Instrument for Data Collection}

A pre-test post-test questionnaire was used to collect data from the participants to measure teachers' knowledge about ADHD. The instrument was the Knowledge of Attention Deficit Disorders Scale (KADDS). This questionnaire was developed by Sciutto, Terjesen, and Bender Frank (2000). Professor Sciutto granted permission through email for the questionnaire used in this study. KADDS is a 30-item scale intended to measure teachers' knowledge and perceptions of ADHD. Every KADDS question is a declaration in reference to ADHD and uses a Yes (Y), No (F), or don't know (DK) structure.

\section{The Intervention}

The package for intervention was taken from the World Health Organization's Mental Health Gap Action Programme Intervention Guide (MhGAP-IG) which was developed to support the delivery of mental health interventions in non-specialist settings. The behavioral disorders module of the MhGAP covers ADHD. The content was used for the training of primary school teachers regarding ADHD. The module covers the symptoms of ADHD, associated impairment, other conditions that need to be excluded, and the treatment options including behavioral interventions and medication. 


\section{Validity and Reliability of Instrument}

The validity of the research instruments was done through face and content validity techniques. For the face and content validity, the researcher sought the opinion of experts related to the field of study including the researcher's supervisor who guided the development of the instrument. The face validity was done to determine the extent to which the instrument covered all the variables to be assessed and its relatedness to the assessment of teachers' knowledge and management of pupils with attention deficit hyperactivity disorder in primary schools in Abeokuta, Ogun State.

\section{Method of Data Analysis}

Data screening was done on the field by the researcher to eliminate outliers and empty questions. Data was analyzed quantitatively using computer software version 21 of the statistical package for social science (SPSS). All research questions were analyzed using descriptive statistics of frequency, percentages, mean and standard deviation.

\section{Ethical Consideration}

Ethical approval was collected from Babcock University Health Research Ethical Committee (BUHREC).

\section{RESULTS/FINDINGS}

\section{Knowledge of ADHD among Respondents}

\begin{tabular}{|c|c|c|c|c|c|c|c|}
\hline & & \begin{tabular}{|l|} 
Pre- \\
intervention
\end{tabular} & & & $\begin{array}{l}\text { Post } \\
\text { intervention }\end{array}$ & & \\
\hline & $\begin{array}{l}\text { Correct } \\
(\%)\end{array}$ & Incorrect $(\%)$ & $\begin{array}{l}\text { I don't } \\
\text { know }(\%)\end{array}$ & $\begin{array}{l}\text { Correct } \\
(\%)\end{array}$ & Incorrect $(\%)$ & $\begin{array}{l}\text { I don't } \\
\text { know }(\%)\end{array}$ & Total (\%) \\
\hline $\begin{array}{l}\text { There is } \\
\text { approximately } 1 \\
\text { child in every } \\
\text { classroom with a } \\
\text { diagnosis of } \\
\text { ADHD }\end{array}$ & $\begin{array}{l}21 \\
(50.0)\end{array}$ & $15(35.7)$ & $6(14.3)$ & $\begin{array}{l}32 \\
(76.2)\end{array}$ & $6(14.3)$ & $4(9.5)$ & $\begin{array}{l}42 \\
(100.0)\end{array}$ \\
\hline $\begin{array}{l}\text { ADHD children } \\
\text { are born with } \\
\text { biological } \\
\text { vulnerabilities } \\
\text { toward } \\
\text { inattention and } \\
\text { poor self-control }\end{array}$ & $\begin{array}{l}19 \\
(45.2)\end{array}$ & $17(40.5)$ & $6(14.3)$ & $\begin{array}{l}33 \\
(78.6)\end{array}$ & $6(14.3)$ & $3(7.1)$ & $\begin{array}{l}42 \\
(100.0)\end{array}$ \\
\hline $\begin{array}{l}\text { A child who is } \\
\text { not overactive } \\
\text { but fails to pay } \\
\text { attention may } \\
\text { have ADHD }\end{array}$ & $\begin{array}{l}11 \\
(26.2)\end{array}$ & $28(66.7)$ & $3(7.1)$ & $\begin{array}{l}27 \\
(64.3)\end{array}$ & $15(35.7)$ & $0(0.0)$ & $\begin{array}{l}42 \\
(100.0)\end{array}$ \\
\hline
\end{tabular}




\begin{tabular}{|l|l|l|l|l|l|l|l|}
\hline $\begin{array}{l}\text { ADHD affects } \\
\text { male children } \\
\text { only }\end{array}$ & $\begin{array}{l}18 \\
(42.9)\end{array}$ & $17(40.5)$ & $7(16.7)$ & $\begin{array}{l}25 \\
(59.5)\end{array}$ & $14(33.3)$ & $3(7.1)$ & $\begin{array}{l}42 \\
(100.0)\end{array}$ \\
\hline $\begin{array}{l}\text { There are } \\
\text { subtypes of } \\
\text { ADHD }\end{array}$ & $\begin{array}{l}19 \\
(45.2)\end{array}$ & $14(33.3)$ & $9(21.4)$ & $\begin{array}{l}25 \\
(59.5)\end{array}$ & $14(33.3)$ & $3(7.1)$ & $\begin{array}{l}42 \\
(100.0)\end{array}$ \\
\hline $\begin{array}{l}\text { ADHD can be } \\
\text { inherited }\end{array}$ & $\begin{array}{l}20 \\
(47.6)\end{array}$ & $12(28.6)$ & $\begin{array}{l}10 \\
(23.8)\end{array}$ & $\begin{array}{l}27 \\
(64.3)\end{array}$ & $8(19.0)$ & $7(16.7)$ & $\begin{array}{l}42 \\
(100.0)\end{array}$ \\
\hline $\begin{array}{l}\text { The cause of } \\
\text { ADHD is } \\
\text { unknown }\end{array}$ & $\begin{array}{l}15 \\
(35.7)\end{array}$ & $18(42.9)$ & $9(21.4)$ & $\begin{array}{l}26 \\
(61.9)\end{array}$ & $12(28.6)$ & $4(9.5)$ & $\begin{array}{l}42 \\
(100.0)\end{array}$ \\
\hline
\end{tabular}

Level of Knowledge of Signs of ADHD among the Respondents

\begin{tabular}{|c|c|c|c|c|c|}
\hline \multirow[t]{2}{*}{$\begin{array}{c}\text { The knowledge of signs and } \\
\text { symptoms of ADHD }\end{array}$} & \multirow[t]{2}{*}{$\begin{array}{l}\text { Category of } \\
\text { scores }\end{array}$} & \multicolumn{2}{|c|}{$\begin{array}{c}\text { Pre- } \\
\text { intervention }\end{array}$} & \multicolumn{2}{|c|}{$\begin{array}{c}\text { Post- } \\
\text { intervention }\end{array}$} \\
\hline & & Freq. & $\%$ & Freq. & $\%$ \\
\hline Low & $<40 \%$ & 27 & 64.3 & 3 & 7.1 \\
\hline Moderate & $40-70 \%$ & 10 & 23.8 & 22 & 52.4 \\
\hline High & $>70 \%$ & 5 & 11.9 & 17 & 40.5 \\
\hline Total & & 42 & 100.0 & 42 & 100.0 \\
\hline Mean & & \multicolumn{2}{|l|}{1.48} & \multicolumn{2}{|l|}{2.33} \\
\hline Standard dev. & & \multicolumn{2}{|l|}{0.71} & \multicolumn{2}{|l|}{0.621} \\
\hline
\end{tabular}

Management of ADHD Student among Respondents

\begin{tabular}{|l|l|l|l|l|l|}
\hline The classroom management & \multirow{2}{*}{$\begin{array}{c}\text { Category of } \\
\text { of ADHD students }\end{array}$} & \multicolumn{2}{|c|}{ Pre-intervention } & \multicolumn{2}{c|}{ Post-intervention } \\
\cline { 3 - 6 } & scores & Freq. & \% & Freq. & $\%$ \\
\hline Bad & $<40 \%$ & 27 & 64.3 & 17 & 40.5 \\
\hline Good & $>40 \%$ & 15 & 35.7 & 25 & 59.5 \\
\hline Total & & 42 & 100.0 & 42 & 100.0 \\
\hline Mean & 1.34 & 1.60 & \\
\hline Standard dev. & 0.48 & 0.50 & \\
\hline
\end{tabular}




\section{Test of Hypotheses}

Ho1: There is no significant relationship between pre intervention knowledge and pre intervention management

\begin{tabular}{|c|c|c|c|c|c|c|c|c|c|}
\hline & \multicolumn{2}{|c|}{\begin{tabular}{|c|} 
Levene's Test \\
for Equality of \\
Variances \\
\end{tabular}} & \multicolumn{7}{|c|}{ t-test for Equality of Means } \\
\hline & \multirow[b]{2}{*}{$\mathrm{F}$} & \multirow[b]{2}{*}{ Sig. } & \multirow[b]{2}{*}{$\mathrm{T}$} & \multirow[b]{2}{*}{ df } & \multirow{2}{*}{$\begin{array}{l}\text { Sig. } \\
(2- \\
\text { tailed })\end{array}$} & \multirow{2}{*}{$\begin{array}{c}\text { Mean } \\
\text { Differenc } \\
\mathrm{e}\end{array}$} & \multirow{2}{*}{$\begin{array}{l}\text { Std. Error } \\
\text { Difference }\end{array}$} & \multicolumn{2}{|c|}{$\begin{array}{l}95 \% \text { Confidence } \\
\text { Interval of the } \\
\text { Difference }\end{array}$} \\
\hline & & & & & & & & Lower & Upper \\
\hline $\begin{array}{l}\text { Equal } \\
\text { variances } \\
\text { assumed }\end{array}$ & 13.572 & 0.001 & -1.412 & 40 & 0.166 & -0.23754 & 0.16817 & -0.57742 & 0.10235 \\
\hline $\begin{array}{l}\text { Equal } \\
\text { variances not } \\
\text { assumed }\end{array}$ & & & -1.567 & 21.733 & 0.132 & -0.23754 & 0.15163 & -0.55223 & 0.07716 \\
\hline
\end{tabular}

\section{DISCUSSION}

This study shows that 19 (45.2\%) participants had low knowledge, 16 (38.1\%) and 7 (16.7\%) had moderate and high knowledge respectively at the pre-intervention stage while at the postintervention stage, $6(14.3 \%)$ had low knowledge score while 9 (21.4\%) and 27 (64.3\%) had moderate and high knowledge scores respectively. At the pre-intervention stage of this study, it was found that 27 (64.3\%) participants had a bad classroom management score of ADHD while $15(35.7 \%)$ had a good classroom management score of ADHD. At the post intervention, $11(26.2 \%)$ participants had a negative towards ADHD, 17 (40.5\%) had a bad classroom management score of ADHD while 25 (59.5\%) had a good classroom management score of ADHD.

Findings from this study show one-third of the participants have had prior training on ADHD and this disagrees with the report of Garcia (2019) who reported that $28 \%$ of teachers have attended courses on ADHD and this low training occurrence might be due to poor awareness about the ADHD or lack of interest on the side of the teachers. Also, the finding of this study showed that $83.3 \%$ of the participants feel confident to support students with ADHD. 


\section{IMPLICATION TO RESEARCH AND PRACTICE}

\section{Nursing Practice}

Nurses should educate the teachers on ADHD so as for them to become resource persons that will help the children with ADHD overcome the challenges associated with it. Hence, nurses should be knowledgeable to educate the teachers as individuals or in groups.

\section{Nursing Research}

The findings of this study can be used as a baseline and reference in their studies. Hence, focus should be on replicating this research in other areas combining the knowledge and attitude of the parents of ADHD children with that of the teachers will be of great importance to nursing research.

\section{CONCLUSION}

The role of teachers in the identification and management of ADHD cannot be overlooked. The study was conducted to assess the teachers' knowledge of ADHD and management of classrooms with ADHD pupils. The findings revealed that the post-intervention knowledge, attitude and classroom management of ADHD improved compared to the pre-intervention assessment of knowledge. This shows that training and proper education of the teachers will go a long way in the management of attention deficit in the pupils. Also, a significant relationship was found in the intervention knowledge of ADHD among the teachers.

\section{SUMMARY}

The study was conducted to assess the effect of nursing intervention on the teachers' knowledge and management of pupils with attention deficit hyperactivity disorder in primary schools in Abeokuta, Ogun State.

The study recruited forty-two (42) teachers from two randomly selected schools in Abeokuta and administered a pre-tested questionnaire including the modified Knowledge of Attention Deficit Disorder Scale (KADDS) for data collection. The data were analyzed using the Statistical Package for Social Sciences (SPSS) version 23.0 for descriptive analysis and ANOVA used in testing relationships between the variables. Significant level was set at $95 \%$ confidence interval.

The results showed that the majority of the participants were in the age group 20-29 years $(40.5 \%)$ and females $(54.8 \%)$. Also, $40.5 \%$ of the participants had working experience of 11 years and above while more than half of them (54.8\%) had the BSc as the educational qualification.

This study also depicted the training and experience of the participants in regards to ADHD. About one-third (33.3\%) had had prior training on ADHD while less than half of them $(26.2 \%)$ had seen suspected cases of ADHD in their pupils, and all of them were willing to attend training on ADHD. Also, the participants learned about ADHD from different sources such as 
books or articles $(54.8 \%)$, internet $(40.5 \%)$ and a large number of them $(83.3 \%)$ feel confident to support pupils with ADHD.

There was a change in the general knowledge of ADHD, signs and symptoms of ADHD, treatment of ADHD and the attitude towards pupils with ADHD among the participants after the intervention was done.

The study showed a significant relationship between the pre- and post-intervention mean scores of participants on knowledge of the participants on ADHD.

\section{Future Research}

Research should be carried out in other schools to assess the teachers' level of knowledge, attitude and classroom management of ADHD. Further studies should be done where the perspective of the parents of ADHD children will be assessed. Further research studies are required to assess the impact of change in teachers' knowledge of ADHD. Further research studies are required to assess the teachers' knowledge of ADHD in two different research settings, that is, the control and intervention groups.

\section{REFERENCES}

Adeosun O., Ogun O., Fatiregun S., Adeyemo (2017). Attitude of Nigerian Primary School Teachers to Children with Attention Deficit Hyperactivity Disorder

Anastopoulos A.D \& Farley S.E(2017). A cognitive behavioral training program for parents of children with attention-deficit/hyperactivity disorder. In AE Kazdin \& JR Weisz (eds). Evidence-based psychotherapies for children and adolescents. New York: Guilford Press.

Barkley R.A (2017). Taking Charge of ADHD: The Complete, Authoritative Guide for Parents. New York: Guilford Press.

Bender, W. N., \& Smith, J. K. (2018). Classroom Behaviour of children and adolescents with learning disabilities: A meta-analysis. Journal of Learning Disabilities, 23, 298-305. Bussing, R., Mason, D. M., Bell.

Bussing, R., Mason, D., Bell, L., Porter, P., \& Garvan, C. (2019). Adolescent outcomes of childhood attention-deficit/ hyperactivity disorder in a diverse community sample. Journal of the American Academy of Child \& Adolescent Psychiatry, 49, 595-605.

Ghanizadeh A. 1, Bahredar MJ, Moeini SR. (2018) Knowledge and attitudes toward attention deficit

Gray, C. A. (2018). Lay and professional constructions of childhood ADHD: a discourse analysis. (Doctoralthesis) Queen Margaret University

Guerra F.,Brown M. (2016) Teacher knowledge of attention deficit hyperactivity disorder among middle school students in South Texas. RMLE Online.; 36(3):1-7. hyperactivity disorder among elementary school teachers. Patient Educ Counselling.;63(1-2):84-86

Hosseinnia M, Mazaheri MA, Heidari Z. Knowledge, attitude, and behavior of elementary teachers regarding attention deficit hyperactivity disorder. Journal of Education and Health Promotion. 2020;9(1):120.

Khalil A., Alshareef F., Alshumrani H. Knowledge, Attitude, and Behavioural Practice of Elementary Teacher of ADHD Children: Impact of an Educational Intervention. American Journal of Nursing. 2019;8(6):329-41. 
Kolb, D. A. (2017). Experiential leaning: experience as the source of learning and development (vol .1). Englewood cliffs, NJ: Prentice-Hall.

Kos J, Richdale A, Hay D (2016). Children with attention deficit hyperactivity disorder and their teachers: a review of the literature. International Journal on Disability Development Education.;53 (2):147-60

Koutrouba, K. (2013). Student misbehavior in secondary education: Greek teachers' views and attitudes. Educational Review, 65(1), 1-19. doi:10.1080/00131911.2011.628122

Koutrouba, K. (2019). Student misbehavior in secondary education: Greek teachers' views and attitudes. Educational Review, 65(1), 1-19. doi:10.1080/00131911.2011.628122

Lasisi D, Ani C, Lasebikan V, Sheikh L, Omigbodun O. Effect of attention-deficithyperactivity-disorder training program on the knowledge and attitudes of primary school teachers in Kaduna, North West Nigeria. Child and adolescent psychiatry and mental health. 2017;11(1):15.

Lasisi D., Ani C., Lasebikan V., Sheikh L., \& Omigbodun O. Effect of attention-deficithyperactivity-disorder training program on the knowledge and attitudes of primary school teachers in Kaduna, North West Nigeria. Child and adolescent psychiatry and mental health. 2017;11(1):15.

Latouche A., \& Gascoigne M., In-service training for increasing teachers' ADHD knowledge and self-efficacy. Journal of attention disorders. 2017;23(3):270-81.

Malen, M. (2018). Teacher ADHD Referral Theory Modification May Reduce Referrals for Student ADHD Diagnosis. (Doctoral Thesis, University of Minnesota, 2018)

McCarthy S, Wilton L, Murray ML, Hodgkins P, Wong ICK.,(2019) The epidemiology of pharmacologically treated attention deficit hyperactivity disorder (ADHD) in children, adolescents and adults in UK primary care. BMC Pediatric;(78):1-11.

Moldavsky M, Sayal K. (2017) Knowledge and attitudes about attention-deficit/ hyperactivity disorder (ADHD) and its treatment: the views of children, adolescents, parents, teachers and healthcare professionals. Curr Psychiatry Rep.15(8):377

Ohan, J., Cormier, N., Hepp, S., Visser, T., \&Strain, M. (2018). Does Knowledge About Attention-Deficit/Hyperactivity Disorder Impact Teachers' Reported Behaviors and Perceptions? School Psychology Quarterly, 23, 436-449.

Oim, A. (2018). Teachers' knowledge and misconceptions concerning attention/deficit hyperactive disorder, learning disabilities and childhood depression (Masters' thesis)

Oke J., Osen S., Adejuyigb E., Mosaku S., (2019) Pattern of attention deficit hyperactivity disorder among primary school children in Ile-Ife, South-West, Nigeria

Perold, M., Louw, C., \& Kleynhans, S. (2019). Primary school teachers' knowledge and misperceptions of attention deficit hyperactivity disorder (ADHD). South African Journal of Education, 30, 457-473.

Polanczyk G, Rohde LA (2017). Epidemiology of attention-deficit/h-ayperactivity disorder across the lifespan. Curr Opin Psychiatry.;20:386-92.

Raman N, Van Rensburg ABRJ. (2017) Clinical and psycho-social profile of child and adolescent mental health care users and services at an urban child mental health clinic in South Africa: original. Afr J Psychiatry. (108):356-63.

Sadock B. J., Sadock V. A. (2019) Kaplan and Sadock's Synopsis of Psychiatry: Behavioral Sciences/Clinical Psychiatry. Lippincott Williams \& Wilkins.

Sciutto MJ, Terjesen MD, Kučerová A, Michalová Z, Schmiedeler S, Antonopoulou K, et.al (2016) Cross-national comparisons of teachers' knowledge and misconceptions of ADHD. Int Perspect Psychol Res Pract Consult. 
Sciutto, M. J. \& Terjesen, M. D. (2014). Psychometric properties of the Knowledge of Attention Deficit Disorders Scale (KADDS). Unpublished test development data.

Veenman B, Luman M, Hoeksma J, Pieterse K, Oosterlaan J. A randomized effectiveness trial of a behavioral teacher program targeting ADHD symptoms. Journal of attention disorders. 2019;23(3):293-304.

Veenman B, Luman M, Hoeksma J, Pieterse K, Oosterlaan J. A randomized effectiveness trial of a behavioral teacher program targeting ADHD symptoms. Journal of attention disorders. 2019;23(3):293-304.

Visser S. N., Danielson M. L., Bitsko R. H., et al (2018). Trends in the parent-report of health care provider-diagnosed and medicated attention-deficit/hyperactivity disorder: United States, 2013-2011. Journal of the American Academy of Child \& Adolescent Psychiatry. 2014;53(1):34-46.e2. doi: 10.1016/j.jaac..09.001.

Westling, D. L. (2010). Teachers and challenging behavior: Knowledge, views, and practices. Remedial and Special Education, 31, 48-63.

Westling, D. L. (2020). Teachers and challenging behavior: Knowledge, views, and practices. Remedial and Special Education, 31, 48-63.

Willcutt, E.G. (2020). The prevalence of DSM-IV attention -deficit hyperactivity disorder: A meta-analytic review. Neurotherapeutics 9 (3), 490-499 